\title{
COMMON FUNDAMENTALS IN THE TEQUILA AND ASIAN CRISES
}

\author{
Aaron Tornell \\ Working Paper 7139 \\ http://www.nber.org/papers/w7139 \\ NATIONAL BUREAU OF ECONOMIC RESEARCH \\ 1050 Massachusetts Avenue \\ Cambridge, MA 02138 \\ May 1999
}

This paper was written during my visit to the Center for Research on Economic Development and Policy Reform at Stanford University. I would like to thank Laura Lindsey and Min Shi for excellent research assistance. Also, I wish to thank Rudi Dornbusch, Elhanan Helpman, Anne Krueger, Paul Krugman, Roberto Rigobon, Andy Rose, Nouriel Roubini, Tom Sargent, and seminar participants at Harvard, the IMF, MIT, Stanford, UCLA, and The World Bank for helpful suggestions. The views expressed herein are those of the authors and do not necessarily reflect the views of the National Bureau of Economic Research.

(C) 1999 by Aaron Tornell. All rights reserved. Short sections of text, not to exceed two paragraphs, may be quoted without explicit permission provided that full credit, including (C) notice, is given to the source. 
Common Fundamentals in the Tequila and Asian Crises

Aaron Tornell

NBER Working Paper No. 7139

May 1999

JEL No. E44, F32

\begin{abstract}
We find that in 1995 and 1997 the crisis did not spread in a truly random way. The crosscountry variation in the severity of the crisis was largely determined by three fundamentals: the strength of the banking system, the real appreciation, and the international liquidity of the country. We also find that the rule that links fundamentals to the crisis severity has been the same in both the Tequila and Asian crises.
\end{abstract}

\author{
Aaron Tornell \\ Department of Economics \\ Harvard University \\ Cambridge, MA 02138 \\ and NBER \\ aaron_tornell@harvard.edu
}




\section{Introduction}

In the aftermath of the 1994 Mexican crisis and the 1997 Thailand crisis there was widespread contagion to several emerging markets. Did these crises spread in a purely random fashion. or is there a set of fundamentals that helps to explain the spread of each crisis? If the latter is true, did the contagion follow the same pattern in both episodes, or was each of a different nature? The answers to these questions are important from both a theoretical as well as a practical standpoint. Theoretically, they might help us to better understand the nature of crises and to discriminate among balance of payments crises models. Practically they might help us to predict future crises, or at least help us to identify countries that will not suffer an attack during turbulent times.

In this paper we will address these issues by considering the following questions. Given the knowledge that a crisis will erupt at a given date in the near future, is it possible to predict which countries will experience an attack? Furthermore, is it possible to determine the relative severity of the crisis across emerging markets? Finally, is the rule that explains the cross-country variation in the severity of the Tequila crisis also applicable to the Asian crisis? It should be noted, however, that we will not attempt to determine the timing of a crisis in this paper.

We find that the Tequila and Asian crises did not spread across emerging markets in a purely random way. Rather, we find that the cross-country variation in the severity of crises can be largely explained by fundamentals, albeit in a nonlinear fashion. We also find that the rule relating fundamentals to crisis severity is the same in both the Tequila and Asian crises. Therefore, had a rule been estimated using data from the Tequila crisis, it would have been possible to reasonably predict the spread of the Asian crisis using data available in late 1996 or early 1997.

The underlying idea of our analysis is as follows. Since the short positions involved in a currency attack entail significant costs, an individual money manager will attack a country only if she expects other money managers to also attack that country, and anticipates that the country will respond with a sizeable depreciation. The eruption of a crisis in a certain 
country indicates to each investor that other investors will attack vulnerable countries in the near future. Although investors do not communicate among themselves, they do not attack countries randomly. They instead use a common set of fundamentals and a stable filtering rule to predict which countries are most likely to respond with sizable depreciations and then concentrate their attacks on those countries. As we will explain in Section 2. these are countries with low international reserves relative to liquid liabilities and with weak fundamentals, i.e. a severe real appreciation and a banking system laden with bad loans.

We measure these fundamentals with a set of indices that can be constructed before the onset of a crisis. We then classify country-years as vulnerable or non-vulnerable, depending on whether or not they have high international liquidity and strong fundamentals. We consider the Tequila and Asian crises, and the emerging markets that have had free and developed financial markets during the 1990s.

We find that within the group of vulnerable cases, the crisis index is increasing in the preceding lending boom and real appreciation. Furthermore, we find that the same model that explains the spread of the crisis in 1995 also explains the cross-country variation in the 1997 crisis. This finding helps explain why in 1995 the hardest hit countries were Latin American, while in 1997 South East Asian countries suffered the most. Prior to the Tequila crises, Latin American countries, on average, had experienced bigger lending booms and more severe real appreciations than South East Asian countries. Interestingly, during the period preceding the Asian crisis the larger lending booms were experienced by South East Asian countries.

We perform several tests to ensure that our results are robust to changes in the definitions of the variables. The same results hold for different groupings of vulnerable and non-vulnerable country-years, and also for different periods over which the crisis index is measured. Furthermore, the results are robust to the elimination of outliers. We also include other variables that have been associated with the occurrence of crises. These variables are government consumption, capital inflows and the current account deficit. We find that there is no change in either the point estimates or the significance levels of the three funda- 
mentals we have considered when we add these variables. Furthermore, estimated coefficients corresponding to the extra variables are not significantly different from zero.

There is a growing literature on the empirical evidence on currency crises, which is surveyed in Lizondo, Kamisky and Reinhart (1998). There are two groups of papers that are closely related to ours. One group concentrates on the predictability of currency crises, the second group investigates contagion across markets. Two approaches have been proposed to predict crises. One, which might be termed the "signals approach:" has been introduced by Kaminsky and Reinhart (1999). They select some macroeconomic series that behave abnormally during periods prior to a crisis. They then produce a warning system based on signals issued by those variables, and assess the individual and combined ability of these variables to predict crises. The other approach has been developed by Frankel and Rose (1996) and Eichengreen, Rose and Wyplosz (1995). These authors compare the evolution of several variables in tranquil times and in crises times. They then estimate the k-step ahead probability of a crisis using multivariate logit and probit models. Berg and Patillo (1998) evaluate the out-of-sample performance of these approaches. Our paper differs from these papers in that we condition on the occurrence of a widespread crisis, and concentrate in explaining the cross-country variation of the severity of the crisis during 1995 and 1997.

Like this paper, the second group of papers concentrates on the determinants of contagion. Sachs, Tornell and Velasco (1996a) tried to explain the spread of the Tequila crisis. Corsetti, Pesenti and Roubini (1998), and Furman and Stiglitz (1998) try to explain the spread of the Asian crisis. Glick and Rose (1998) find that countries with important trade links to the country that first experienced a crisis are more likely to experience a crisis themselves. Their approach differs from ours in that they condition both on the timing and the country that was first hit by the crisis, while we condition only on the timing. Both papers should be considered as complementary since in all likelihood the spread of crises is determined by trade links, as well as by the macroeconomic fundamentals we consider.

The structure of the paper is as follows. In section 2 we present the conceptual framework and a simple model. In section 3 we present the empirics. Section 4 contains the conclusions. 
Lastly, the appendix describes how the indices were constructed.

\section{Conceptual Framework}

In order to determine which countries are most likely to suffer a speculative attack during a generalized crisis, we will consider the thought processes of risk neutral money managers and government officials across emerging markets. Since the short positions involved in a currency attack entail significant interest rate costs, an individual money manager will attack a country only if (i) she expects that other money managers will also attack that country; and (ii) she expects that the country in question will respond with a sizable depreciation.

In order for the first condition to be satisfied, it is necessary that money managers coordinate with each other in selecting which currencies should be attacked and on the timing of the attack itself. Since not all money managers can communicate with each other, a coordinating device is needed. In this respect, the eruption of a crisis in some emerging market acts (or reflects) the signal emitted by a coordinating device. This signal indicates to money managers that others might attack certain currencies in the near future. Although money managers cannot communicate among themselves, they will concentrate their attacks on currencies that are expected to react with a sizable depreciation in response to a capital outflow.

A country might respond to an attack by simply running down reserves, by increasing its interest rate, or by depreciating. The first option may be the least politically costly, but it is available only to governments with plenty of reserves to cover their liquid liabilities. Thus, it is not an option open to the majority of countries as their short run liabilities far exceed their reserves. In this case governments are faced with a difficult choice between two unpleasant alternatives. Increasing the interest rate makes speculation against the currency more expensive, and it can help close the external gap by reducing absorption. Yet the effects come at the cost of a recession. In emerging markets, the health of the banking system is a very important determinant of the effect that increasing interest rates will have on the 
economy. When the banking system has a large share of bad loans, a given interest rate increase is more likely to induce a big recession or even a meltdown of the payments system. Thus, money managers know that if the banking system is weak, it is not likely that the government will respond to an attack with an interest rate hike.

In these circumstances, i.e., low reserves and weak banks, a government will be forced to close the external gap through a depreciation. What is the extent of the depreciation the government will have to engineer in order to close a given external gap? The greater the real appreciation has been during the previous few years, the more likely it is that firms in the tradable sector have shifted to the non-tradable sector, and therefore the lower the response of tradeables to a real depreciation, and the greater the nominal depreciation necessary to close the external gap.

In summary, when a currency crisis erupts in an emerging market, money managers will expect others to attack those countries that are most likely to respond with a sizable depreciation. Thus, the crisis is not likely to spread to countries with either (1) high reserves, or (2) with low reserves, but with strong banks or no severe real appreciation. In contrast, the crisis is likely to reach countries with low reserves, weak banks and a severe real appreciation.

\subsection{A Minimal Model}

In order to make our ideas more concrete we present a very stylized model. The objective is simply to formalize the mechanisms through which the concurrence of a weak banking system, a severe real appreciation and low international liquidity makes it highly likely that a crisis will spread to a certain country. The model is static, and focuses on the interaction between investors' devaluation expectations and the government's management of the external gap in the very short run. It disregards the intertemporal aspects of both individual and government behavior. Such aspects are the focus of intertemporal models of balance of payments crises with multiple equilibria, such as those developed by: Calvo (1995), Cole and Kehoe (1996), Obstfeld (1995), and Sachs, Tornell and Velasco (1996b).

Consider a small open economy where there are many identical small investors who 
initially hold an aggregate stock $M$ of deposits denominated in domestic currency that pay an interest rate $r$. The sequence of events goes as follows. First, each investor chooses the stock of domestic deposits she wishes to hold and the amount she wishes to convert into foreign currency. Then the government decides whether to respond by running down reserves, by increasing unemployment or by depreciating the currency. Finally, investors cash their deposits plus the interest accrued.

Since the world interest rate is $r^{*}$, a risk neutral investor will hold domestic deposits as long as $\frac{1+r}{1+\pi_{j}^{e}} \geq 1+r^{*}$, where the initial exchange rate is 1 and $\pi_{j}^{e}$ is the devaluation rate expected by investor $j$. That is, investor $j$ will be willing to hold domestic deposits only if the devaluation rate she expects is no greater than the threshold

$$
\bar{\pi}=\frac{r-r^{*}}{1+r}
$$

To simplify the exposition we assume that each investor can either hold a stock $m$ or 0 of domestic deposits. It follows that investor $j$ 's strategy is:

$$
\Delta m_{j}^{d}\left(\pi_{j}^{e}\right)= \begin{cases}0 & \text { if } \pi_{j}^{e} \leq \bar{\pi} \\ -m & \text { if } \pi_{j}^{e}>\bar{\pi}\end{cases}
$$

In a symmetric equilibrium all investors derive the same conclusions from the signals they receive. Thus, the change in aggregate deposits $\Delta M^{d}$ is equal to either $-M$ or 0 , where $M$ denotes the aggregate initial stock of deposits.

When computing the expected rate of depreciation investors take into account the problem faced by the government, to which we turn next. The home government has an initial stock $R$ of international reserves. Taking as given $\Delta M^{d}$, the government chooses the change in reserves $\Delta R$, the depreciation rate $\pi$, and the unemployment rate $u$, in order to minimize the following loss function

$$
\min _{\Delta R, \pi, u}[\pi+\alpha u]
$$

subject to the balance of payments equation (where $C A$ is the current account)

$$
\frac{\Delta M^{d}}{1+\pi}=\Delta R-C A(\pi, u)
$$


and subject to:

$$
\Delta R \geq-R, \quad \pi \geq 0, \quad u \in[0, \bar{u}(b l)] \quad \bar{u}^{\prime}(b l)<0
$$

The loss function (3) says that the government dislikes inflation and unemployment, but does not care about international reserves (i.e., there is no immediate political cost associated with depletion of reserves). The parameter $\alpha$ captures how sensitive the government is to recessions. The upper bound on unemployment $\bar{u}(b l)$ in (5) captures the idea that it is virtually impossible to increase unemployment (and interest rates) beyond a certain point without causing generalized bankruptcies and a meltdown of the payments system. We have made this upper bound decreasing in the share of bad loans in the banks' portfolios (bl). The higher this share, the more vulnerable the banks are to an increase in unemployment.

In the very short-run the government can improve the current account by increasing unemployment or, since prices are predetermined in the short run, by engineering a nominal depreciation. We will represent the current account in a linear way. This does some minor violence to the standard formulation, but greatly simplifies the computations that follow.

$$
C A=\theta(r e r) \cdot \pi+u(b l)-H(r e r), \quad \theta^{\prime}>0, \quad H^{\prime}<0
$$

The term $-H($ rer $)$ captures the negative effects of past real appreciation on today's current account. For instance, it measures today's service on the debt associated with past current account deficits. The coefficient $\theta(r e r)$ indicates how effective a nominal devaluation is in improving the current account. It may proxy for the degree of wage stickiness in the short - run, or for the slope of the transformation curve between tradeables and non-tradeables: the greater $\theta$, the less concave the transformation curve. The more appreciated the real exchange rate has been, the lower $\theta\left(\theta^{\prime}>0\right)$. This is because a larger share of producers have shifted from the tradable to the nontradable sector, and therefore the less a real depreciation will increase the production of tradables in the short run. We will assume throughout that parameters satisfy $\sqrt{\frac{\alpha M}{1-\alpha \theta}} \geq 1$.

In a symmetric rational expectations equilibrium the government takes $\Delta M^{d}$ as given and chooses $(\Delta R, \pi, u)$ in order to maximize (3) subject to (4) and (5); all investors follow strategy (2); and the actual and expected devaluation rates are equal: $\pi=\pi^{e}=\pi_{j}^{e}$. 
Consider the government's problem. There are three cases, depending on the size of reserves. First, if international reserves are sufficient to cover any potential capital outflow plus the current account deficit, the government will find it optimal to close the external gap by running down reserves. That is, for any withdrawal policy of investors $\Delta M\left(\pi^{e}\right)$, the government's best response is:

- If $R \geq M+H($ rer $)$, then

$$
\begin{aligned}
& \Delta R^{*}\left(\Delta M^{d}\right)=\Delta M-H(\text { rer }) \\
& \pi^{*}\left(\Delta M^{d}\right)=0 \\
& u^{*}\left(\Delta M^{d}\right)=0
\end{aligned}
$$

When reserves are in an intermediate range, the government's policy depends on expectations. That is:

- If $H($ rer $) \leq R<M+H($ rer $)$ and $\pi^{e} \leq \pi$, then $\Delta R^{*}, \pi^{*}$, and $u^{*}$ are given by (7).

- If $H($ rer $) \leq R<M+H($ rer $)$ and $\pi^{e}>\pi$, then

$$
\begin{gathered}
\Delta R^{*}\left(\Delta M^{d}\right)=-R \\
\pi^{*}\left(\Delta M^{d}\right)=\left\{\begin{array}{cc}
\sqrt{\frac{\alpha M}{1-\alpha \theta}}-1 & \text { if } \Gamma \leq \bar{u} \\
\frac{-[E+\theta]+\sqrt{[E+\theta]^{2}+4 \theta[M-E]}}{2 \theta} & \text { if } \Gamma>\bar{u}
\end{array}\right. \\
u^{*}\left(\Delta M^{d}\right)= \begin{cases}\Gamma & \text { if } \Gamma \leq \bar{u} \\
\bar{u} & \text { if } \Gamma>\bar{u}\end{cases}
\end{gathered}
$$

where: $E \equiv \bar{u}+R-H$ and $\Gamma \equiv \frac{1-2 \alpha \theta}{\sqrt{\alpha[1-\alpha \theta]}} \sqrt{M}-R+H($ rer $)$.

Lastly, when reserves are very low $(R<H)$, regardless of the value of $\Delta M^{d}$, the government will set $\Delta R^{*}=-R$ and close the external gap by setting the depreciation and unemployment rates equal to (9) and (10).

The intuition is as follows. The government prefers to close the external gap by running down its reserves. However, once reserves are depleted the gap must be closed by either a 
depreciation or by inducing a recession. If the external gap $(M+H(r e r))$ is not very large relative to the maximum feasible unemployment $(\bar{u})$, then the government will trade-off the costs and benefits of unemployment and devaluation as measured by $\alpha$ and $\theta$. The optimal choices of unemployment and devaluation are given by the first row of (9) and (10). However, as the external gap increases beyond a certain threshold, the government will be forced to close the gap exclusively through further depreciation, as shown in the second row of (9).

We find the symmetric rational expectations equilibria by combining the investors withdrawal policy (2) and the government's strategy (8)-(10). There are three cases

Case 1. $\pi^{*}(-M) \leq \bar{\pi}$. There is a unique symmetric equilibrium

$$
\Delta \widehat{M}^{d}=0 \text { and } \widehat{\pi}=\pi^{*}(0)
$$

Case 2. $\bar{\pi} \in\left[\pi^{*}(0), \pi^{*}(-M)\right)$. There are two symmetric equilibria

$$
\begin{aligned}
& \Delta \widehat{M}^{d}=0 \text { and } \widehat{\pi}=\pi^{*}(0) \\
& \Delta \widehat{M}^{d}=-M \text { and } \widehat{\pi}=\pi^{*}(-M)
\end{aligned}
$$

Case 3. $\bar{\pi}<\pi^{*}(0)$. There is a unique symmetric equilibrium

$$
\Delta \widehat{M}^{d}=-M \text { and } \hat{\pi}=\pi^{*}(-M)
$$

In case 1 an attack never occurs. This is the situation where reserves are high or fundamentals are strong. When $R \geq M$, the government will respond to any $\Delta M^{d}$ by running down reserves and setting $\pi=0$. Knowing this, investors set $\Delta M^{d}=0$ regardless of fundamentals. When fundamentals are strong (i.e., there are neither many bad loans nor severe real appreciation) the devaluation needed to close the external gap is smaller than $\bar{\pi}$. Thus, investors have no reason to withdraw their deposits.

Cases 2 and 3 occur when reserves are low and fundamentals are weak. In case 2 there are multiple equilibria. In the crisis equilibrium investors believe that the devaluation will be greater than $\bar{\pi}$ and consequently withdraw their deposits. As a result the devaluation is 
indeed greater than $\bar{\pi}$. In the no-attack equilibrium investors believe the opposite, and do not withdraw their deposits. Thus, depreciation is no greater than $\bar{\pi}$. In case 3 fundamentals are so weak that the government will have to depreciate more than $\bar{\pi}$ regardless of investors: expectations.

In order to link the model with the discussion at the beginning of this section, suppose that a certain coordinating device emits a signal that indicates to investors that the other investors will withdraw their deposits from countries that belong to case 2 . In this situation countries that belong to case 1 will not suffer attack. In countries that belong to case 2 the signal will turn investors into pessimists, leading them to withdraw their deposits. Furthermore, within the case 2 countries, those with weaker fundamentals will experience greater depreciation. One could also consider the eruption of a crisis in a certain country as the coordinating device. This country should be the first to shift from case 2 to case 3 .

In order to give empirical content to the model consider two countries: ' $S$ ' and ' $W$ '. Country ' $S$ ' has sufficiently high reserves or has neither a large share of bad loans nor a severe appreciation. Clearly, country 'S' corresponds to case 1. Therefore, it will not suffer an attack. Country ' $W$ ' has low reserves, a high share of bad loans and a severe real appreciation. This country clearly corresponds to either case 2 or 3 . Recall that the relative efficiency of a devaluation in reducing the external gap is decreasing in the extent of real appreciation $\theta^{\prime}($ rer $)>0$, and that the upper bound on unemployment is decreasing in the share of bad loans $\bar{u}^{\prime}(b l)<0$. Therefore, country ' $W$ ' will not be able to close the external gap by simply running down reserves because the current account deficit $H(r e r)$ is likely to be larger than reserves. Furthermore, since country ' $W$ ' has a low $\theta$, it is clear from the first row in (9) that it is more efficient to close the gap by increasing unemployment than by depreciating. However, since the share of bad loans is high, country ' $W$ ' has a very low $\bar{u}(b l)$. Therefore, the brunt of the adjustment will have to come from a huge depreciation. It is in this situation, of low reserves and weak fundamentals, that an attack and excessive depreciation take place. 


\section{Empirics}

The key point of the previous section is that crises do not spread in a purely random way across emerging markets. Instead, investors concentrate their attacks in countries that are very likely to respond with an excessive depreciation. These countries are the ones with very low reserves relative to liquid liabilities, weak banking systems and a severe real exchange rate appreciation. There are several ways to measure these three concepts and thus the severity of a crisis. In this paper, we have chosen to proxy these variables with indices that are available in data sources, such as the International Financial Statistics, where one might be confident that the same definitions have been applied to all countries. Note that the data has to be available on a timely basis if this exercise is to have any connection with the decision rules used by money managers. In the end, we would like the rule we derive to apply to future currency crises in emerging markets. Therefore, the formulas used to construct the proxies for the variables we are interested in will be as simple as possible. By interacting several variables in a non-linear way, we could produce indices that eliminate "nasty" observations and ensure that we could explain a specific episode fairly well. The drawback to this approach is that the rule so derived might not explain other crises.

The appendix contains a detailed explanation of how the indices are constructed. Here we simply present a description of these indices. We start with the measurement of the crisis. The crisis indices we consider are weighted averages of the loss in reserves and the depreciation against the US Dollar. The initial point is the month before the onset of the crisis (November 1994, or May 1997). Then, we vary the terminal month over a period of six months starting in January 1995 or July 1997. The weights given to the loss in reserves and the devaluation are country-specific, and are inversely related to the relative variance of each series. The rationale for measuring the crisis in this way is that authorities will typically respond to an attack by running down reserves, depreciating and increasing interest rates. We do not include interest rate changes in the index because there is no data for all the countries we consider.

Ideally, one should measure the weakness of the banking system with the "true" share 
of bad loans. Unfortunately, this information is available neither on a timely basis nor in data sources that ensure cross-country comparability. For instance, suppose that country "a" has a smaller "true" bad-to-total loans ratio than country "b", but "a" has adopted US GAAP accounting rules, while country " $b$ " has not. In this case, it is very likely that " $b$ " might report a smaller bad loans ratio because it only classifies the debt service that is delinquent as a bad loan. In contrast, country "a" will consider the entire stock of the delinquent debt as a bad loan. A second problem that arises is misreporting, or the so-called "evergreen accounts problem." Banks (and often regulators) have incentives to disguise the fact that there are non-performing loans. Hence, banks will simply continue to lend to the non-performing accounts an amount equivalent to the payments they were supposed to make. This cultivation of evergreen accounts can go on for a long period of time without market participants noticing the problem. This brings us to the third problem, namely that information on non-performing loans is not available on a timely basis. For instance, money managers that were looking at the Mexican bad loans ratio in 1994 saw acceptable numbers. The recognition of a sizable share of bad loans did not come until after the crisis had erupted.

For these reasons, we proxy the weakness of the banking system with a lending boom index. This variable is available on a timely basis and is comparable across countries. We measure the "lending boom" as the real percent increase in loans provided by the banking system to the private sector and state-owned enterprises over the previous four years. We should expect that the greater the increase of loans provided by the banking system during a short span of time, the greater the share of bad loans in the subsequent period would be. There are several reasons why this is true. First, banks have limited capacity to evaluate projects. Second, regulatory agencies have limited monitoring capacity and resources. Last, there exists a limited supply of "good" projects with high expected returns relative to their variance. Note that even if a country is experiencing a sharp increase in output, we should expect a lending boom to weaken the banking system. This is because at least one of the three mechanisms described above will be operative.

We measure the real exchange rate as a weighted average of the bilateral real exchange 
rates of a given country with respect to the US dollar, the Mark, and the Yen. The weights add up to one and are proportional to the shares of bilateral trade in the given country with the US, the European Union, and Japan, respectively. Our real depreciation index is the percentage change in this index over the four years prior to the onset of the crisis. i.e.. December 1994 relative to December 1990, and December 1996 relative to December 1992. The problems associated with measuring real depreciation in this way are well understood, so we will not discuss them here.

We proxy the government's liquidity by the ratio of M2 to reserves in the month preceding the onset of the crisis (November 1994 or May 1997). If the central bank is not willing to let the exchange rate depreciate, it must be prepared to cover all the liabilities of the banking system with reserves. Thus, it is $\mathrm{M} 2$, and not simply the monetary base, that must be the relevant proxy of the central bank's contingent liabilities. During a crisis banks are likely to experience runs. If the central bank does not act as a lender of last resort, generalized bankruptcies are likely to follow. Since, in most circumstances, authorities will not find it optimal to allow the economy to experience generalized bankruptcies, the central bank will have to be prepared to exchange the amount withdrawn by depositors for foreign exchange.

Our sample consists of the developing countries listed in the "Emerging Stock Markets Factbook" of the International Finance Corporation, with the exception of (1) Greece and Portugal, as they belong to the European Union and are not developing countries; (2) China, because there is no free convertibility; and (3) Nigeria, because there is no data availability. Thus, our sample consists of Hong Kong and 22 countries: Argentina, Brazil, Chile, Colombia, Hungary, India, Indonesia, Korea, Jordan, Malaysia, Mexico, Pakistan, Peru, The Philippines, Poland, South Africa, Sri Lanka, Taiwan, Thailand, Turkey, Venezuela, and Zimbabwe. Note that these countries have had free convertibility, and financial markets in which foreigners could freely invest during the 1990s.

We consider the two generalized emerging market currency crises that have occurred in the 1990s. Previous crises, like the debt crisis of the early 1980s, were of a different nature and are not considered. In those cases, financial markets in emerging markets were not yet 
liberalized, and the majority of capital inflows took the form of loans to governments by large foreign banks or official agencies. The currency crises of the 1990s have happened under different conditions and thus, we should expect different mechanisms to be at work.

\subsection{The Benchmark Regression}

As was mentioned earlier, our goal is not to determine when a crisis will occur, but rather in the event that it does occur, how it will spread across emerging markets. In other words, our objective is to determine the cross-country variation in the crisis index conditioning only on the timing of the crisis, not on the country in which it first hits. Furthermore, the same rule should determine the cross-country variation of the crisis indices in the 1994 and 1997 crises.

As was discussed in the previous section, the onset of a crisis occurs when a coordinating device emits a signal. This signal will alert each investor to a coming attack on some emerging market by all other investors. The countries that are most likely to respond to an attack with an excessive depreciation will be the targets of an attack. These are countries with weak fundamentals and low reserves. Furthermore, within this subset of countries, the more severe the lending booms and the real appreciation, the more resources will be allocated to attack it and the greater the crisis index. In contrast, countries with high reserves or strong fundamentals will not be targeted by investors. As a result, we should not expect that variations in the explanatory variables should affect the crisis indices in this subset of countries.

We implement these ideas empirically by classifying observations into four groups: high and low reserves cases, and strong and weak fundamentals cases. In our benchmark regression we classify most country-years as being those with low reserves and weak fundamentals. Then, we consider more and less stringent definitions of the vulnerable region, and see how robust our results are to such changes.

In the benchmark case a country-year has high reserves $\left(D^{h r}=1\right)$ if its M2/Reserves ratio is below 1.8. A country-year has strong fundamentals $\left(D^{s f}=1\right)$ if its lending boom is below 
$0 \%$ and its real exchange rate appreciation is lower than $5 \%$. The group with high reserves includes 7 country-years while the group with strong fundamentals includes 5 country-years. Later on we change the thresholds that define the dummies and analyze the robustness of our results.

In the benchmark we stack the 46 observations for the 1994 and 1997 crises, and estimate the following regression using ordinary least squares.

$$
\begin{aligned}
\text { Crisis }_{i t}= & \alpha_{0}+\alpha_{1} L B_{i t}+\alpha_{2} R E R_{i t}+\alpha_{3} D^{h r} \cdot L B_{i t}+\alpha_{4} D^{h r} \cdot R E R_{i t} \\
& +\alpha_{5} D^{s f} \cdot L B_{i t}+\alpha_{6} D^{s f} \cdot R E R_{i t}+\epsilon_{i t}
\end{aligned}
$$

where $i$ indexes the country and $t$ indexes time. Below we investigate whether country effects are present.

The effects of the lending boom and real appreciation in the case of weak fundamentals and low reserves are captured by $\alpha_{1}$ and $\alpha_{2}$, respectively. Theory predicts that when there is fragility, the crisis will be greater if the lending boom is large (i.e. $\alpha_{1}>0$ ) and the real appreciation is high (i.e. $\alpha_{2}<0$ ). The effects of the lending boom and real appreciation for the case of high reserves are captured by $\alpha_{1}+\alpha_{3}$ and $\alpha_{2}+\alpha_{4}$, respectively. Meanwhile, in the case of strong fundamentals, these effects are captured by $\alpha_{1}+\alpha_{5}$ and $\alpha_{2}+\alpha_{6}$, respectively. According to the theory, if there is no fragility $\left(D^{h r}=1\right.$ or $\left.D^{s f}=1\right)$, neither a greater lending boom nor a greater appreciation will have any effect on the investors' decision to attack. Thus, we expect to find that $\alpha_{1}+\alpha_{3}=\alpha_{2}+\alpha_{4}=0$, and $\alpha_{1}+\alpha_{5}=\alpha_{2}+\alpha_{6}=0$.

For our benchmark we consider the crisis index that corresponds to the four months after the onset of the crisis. In the Tequila crisis we look at November 94-March 95 and for the Asian crisis, we consider May 97-September 97. Below we show how the estimates change as we vary the crisis index. The estimated regression is

$$
\begin{aligned}
& \text { Crisis }_{i t}=\begin{array}{cccc}
-4.25 & +0.26 L B_{i t} & -0.12 R E R_{i t} & -0.26 D^{h r} \cdot L B_{i t} \\
(4.14) & (0.11) & (0.06) & (0.11)
\end{array} \\
& -0.25 D^{h r} \cdot R E R_{i t}+0.00 D^{s f} \cdot L B_{i t}+0.30 D^{s f} \cdot R E R_{i t}+\epsilon_{i t} \\
& \text { (0.36) } \\
& (0.26) \\
& R^{2}=0.48, \quad \bar{R}^{2}=0.40, \quad N=46
\end{aligned}
$$


Newey-West Heteroscedasticity adjusted standard errors appear in parentheses ${ }^{1}$. These estimates agree with the theory presented earlier. First, for countries with weak fundamentals and low reserves, the coefficients corresponding to the lending boom $\left(\alpha_{1}\right)$ and the real appreciation $\left(\alpha_{2}\right)$ are significantly different from zero at the $5 \%$ level. The point estimates indicate that: (i) a one unit increase in the LB index for a country-year with low reserves and weak fundamentals leads to a 0.26 unit increase in the crisis index of that country-year relative to the average of our emerging markets sample; (ii) a one unit increase in the real appreciation index leads to a 0.12 increase in the crisis index relative to the average. Second. as expected, neither the LB index nor the RER enter significantly in countries with high reserves. In these cases, the corresponding point estimates are $\alpha_{1}+\alpha_{3}=0$ and $\alpha_{2}+\alpha_{4}=$ - .37. Furthermore, Wald tests indicate that the hypotheses $\alpha_{1}+\alpha_{3}=0$ and $\alpha_{2}+\alpha_{4}=0$ cannot be rejected (the associated p-values are 0.85 and 0.33 , respectively). Similarly, in countries with strong fundamentals, neither LB nor RER affect the severity of the crisis. The p-values associated with Wald tests of the hypotheses that $\alpha_{1}+\alpha_{5}=0$ and $\alpha_{2}+\alpha_{6}=0$ are 0.30 and 0.23 , respectively.

Figure 1 plots the actual crisis indexes and the fitted values. As can be seen, with a few notable exceptions, the fitted values match the actual crisis indices quite well. The exceptions are: Mexico 94, Indonesia 97, Thailand 94, and Thailand 97.

In summary, the regression results support the idea that currency crises do not spread in a purely random way. One can predict-with fair confidence-that a crisis will spread

\footnotetext{
${ }^{1}$ If we include in the benchmark regression two extra terms with the dummies: $\alpha_{8} D^{h r}$ and $\alpha_{9} D^{s f}$, the point estimates and signiificance levels of $\alpha_{1}$ and $\alpha_{2}$ remain unchanged

$$
\begin{gathered}
\text { Crisis }_{i t}=\begin{array}{ccccc}
-4.77 & +0.26 L B_{i t} & -0.12 R E R_{i t} & -0.28 D^{h r} \cdot L B_{i t} & -0.30 D^{h r} \cdot R E R_{i t} \\
(4.30) & (0.11) & (0.06) & (0.11) & (0.15) \\
+0.94 D^{s f} \cdot L B_{i t} & -0.10 D^{s f} \cdot R E R_{i t} & +8.67 D^{h r} & +24.47 D^{s f}+\epsilon_{i t} \\
(0.80) & (0.60) & (5.00) & (25.07)
\end{array} \\
R^{2}=0.49, \quad \bar{R}^{2}=0.38, \quad N=46
\end{gathered}
$$


to countries that are vulnerable. A country is vulnerable to an attack if it has had an appreciated real exchange rate for the past few years, or if it has experienced a lending boom, thus increasing the likelihood that its banking system is laden with bad loans. Both effects point in the direction of a higher expected depreciation, unless the country in question has sufficient international reserves relative to its short-term liabilities. In this case, the best response of the government might be to defend the peg.

A few examples illustrate how the combination of these three fundamentals can help us explain some puzzling cases. If we look at Peru, for instance, we see that over the 4 years prior to the Tequila crisis it had experienced a similar appreciation and a greater lending boom than Mexico. However, Peru's crisis index was only -2.7, while Mexico's was 79.3. This can be explained by the fact that Mexico was illiquid, while Peru was not. In fact, in November 1994, the ratio of M2 to reserves was 1.3 for Peru and 9.3 in Mexico.

\subsection{Country Effects}

In our sample there are two observations per country, one corresponding to the Tequila crisis and the other to the Asian crisis. At this point, the question arises as to whether or not country effects are present. In order to determine the correct specification we consider three different models: the simple OLS model presented in equation (12), a fixed effects model, and a random effects model. The simple OLS model assumes that there are no country effects, so that equation (11) is the correct specification. In contrast, the fixed effects model assumes that there are country effects and that they are constant through time. Thus, the constant term $\alpha_{0}$ in equation (11) is replaced by 23 terms of the form $\alpha_{0 i} * D^{i}$, where $D^{i}$ is a dummy that equals one if the observation corresponds to country $i$. Lastly, the random effects model considers country-specific effects as randomly distributed across countries. Hence, the estimated model is (11) plus $u_{i}$, where $u_{i}$ is a random disturbance corresponding to country $i$.

As we can see in Table 1, the estimated coefficients of the simple OLS and random effects models are identical ( 0.26 and -0.12 , respectively). The estimates for the fixed effects model 
have the same signs as the OLS estimates, however, the point estimates are slightly different (0.32 and -0.22 , respectively).

To test the null hypothesis of no country-specific effects against the alternative that there are country-specific fixed effects we perform an $F$ test. That is, under the null, all coefficients $\alpha_{0 i}$ 's are equal. The $F$ statistic is

$$
F[22,17]=\frac{[0.8157-0.4836] / 22}{[1-0.8157] / 17}=1.39
$$

Since the $1 \%$ critical value from the $\mathrm{F}$ table is 3.1 , we cannot reject the null hypothesis of no fixed effects.

To test the null hypothesis of no country effects against the alternative of random effects, we perform a Breusch Pagan test. Now the null hypothesis is that the variance of the residuals $u_{i}$ 's is zero. The test statistic is $\mathrm{LM}=0.0659$. Under the null, the LM statistic is distributed as chi-squared with six degrees of freedom. Since 0.0659 is lower than the $1 \%$ critical value, we cannot reject the null hypothesis of no random effects.

From the two preceding tests, we conclude that the simple OLS model of equation (11) is an appropriate specification. Thus, in the remainder of the paper we will use regression equation (12) as our benchmark.

\subsection{Structural Change}

At this point in the analysis, a natural question arises as to whether the same model that explains the spread of the crisis in 1995 also explains the cross country variation in the 1997 crisis, or whether there was, in fact, a structural change. The first column of Table 2 shows the estimates of the benchmark regression that includes the Tequila and Asian crisis. The second and third columns show the estimates of regression equation (11) for the 1994 and 1997 crises, respectively. The point estimates for the country-years with weak fundamentals and low reserves are very similar. The coefficient corresponding to the lending boom $\left(\alpha_{1}\right)$ are $0.26,0.30$, and 0.21 , respectively. Those corresponding to the real exchange rate depreciation $\left(\alpha_{2}\right)$ are $-0.12,-0.23$, and -0.06 , respectively. 
To test the hypothesis that the coefficients in equation (11) are the same in both periods we perform a Chow test. The test statistic is

$$
F[7,32]=\frac{[5946-4042-1432] / 7}{[4042-1432] / 32}=0.39
$$

Since the critical value at the $1 \%$ level is 3.3 , we cannot reject the hypothesis that the sets of coefficients are the same in the two periods.

Next, we test whether the two coefficients that interest us most $\left(\alpha_{1}\right.$ and $\left.\alpha_{2}\right)$ are the same in both periods. To do this, we first add the term $\alpha_{8}{ }^{*} \mathrm{LB}^{*} \mathrm{D} 97$ to equation (11), where D97 takes the value of one for observations that correspond to the 1997 crisis. It follows that in countries with weak fundamentals and low reserves, the effect of the lending boom on the crisis index is $\alpha_{1}$ for the 1994 crisis and $\alpha_{1}+\alpha_{8}$ for the 1997 crisis. Therefore, the null hypothesis is $\alpha_{8}=0$. As can be seen in Column (4) in Table 2, the estimate of $\alpha_{8}$ is not different from zero at the usual significance levels. Next, we perform the same test for the real exchange rate depreciation. Column (5) in Table 2, shows the estimation results for equation (11) adding the extra term $\alpha_{9}{ }^{*} \mathrm{RER}^{*} \mathrm{D} 97$. In this case the estimate for $\alpha_{9}$ is significantly different from zero at the $10 \%$ level.

\subsection{Predicting the Asian Crisis}

Suppose a crystal ball had predicted that a crisis would erupt in mid 1997 and suppose a money manager had estimated the model of equation (11) using data from the 1994 crisis. How well would she predict the spread of the crisis across emerging markets? Note that we are not asking "when will the next crisis erupt."

Towards this end, we will construct an out-of-sample predicted crisis index by substituting in equation (11): (a) the estimated coefficients of a regression that uses only data from the 1994 crisis; and (b) the explanatory variables that correspond to the 1997 crisis, i.e., the lending boom and the real depreciation over the period 1992-1996, and the ratio of M2 to reserves of May 1997. The resulting predicted crises indices are depicted as the dashed line in Figure 2. The solid line represents the actual crisis indices, while the dotted lines represent 
the fitted values of the regression using only the data from 1997. As can be seen in Figure 2, the predicted crises indices using 1994 data are quite similar to the fitted crises indices that include 1997 data.

To measure how well the out-of-sample prediction fits the actual crisis indices of 1997 we regressed the actual crisis indices of 1997 on the predicted out-of-sample crisis indices:

$$
\begin{aligned}
97 \text { Crisis }_{i}= & 0.65 \cdot\left[\text { out }- \text { of }- \text { sample predicted } 97 \text { crisis }_{i}\right] \\
& +\nu_{i} \\
& \left.R^{2}=0.17\right)
\end{aligned}
$$

The regression coefficient is 0.65 , and it is significantly different from zero at the $1 \%$ level. Thus, we see that, by using the 1994 model, one would not have fared badly in predicting which countries would have been hard hit in 1997. Of course, there is estimation risk.

\subsection{Robustness}

Here we analyze whether the results of the benchmark regression equation (12) are robust to changes in the period over which the crisis index is measured, alternative definitions of the dummies, and to the elimination of outliers.

\subsubsection{The Crisis Index}

In order to analyze whether the results are robust to changes in the period over which the crisis index is measured, we estimate equation (11) using six crises indices. For all indices, the starting point is the month preceding the onset of the crisis (i.e. November 1994 for the Tequila crisis and May 1997 for the Asian crisis). Then, we vary the terminal month over a period of six months starting in January 1995 or July 1997. As Table 3 shows, in columns (4) through (6) the point estimates and significance levels are similar to those of the benchmark regression (column (3)). Moreover, the estimate of $\alpha_{1}$ (that corresponds to the lending boom) is significantly different from zero at the $5 \%$ level in all columns, and the point estimates in columns (4)-(6) are very similar to the benchmark estimate of 0.26 . 


\subsubsection{Alternative Definitions of the Dummies}

In the benchmark regression, a country-year is classified as having high reserves if, at the onset of the crisis, its ratio of M2 to reserves is lower than 1.8. According to this criterion, 7 cases had high reserves. Under the benchmark, a country has strong fundamentals if its lending boom variable is negative and its real appreciation is less than $5 \%$ (this yields 4 country-years). The second and third columns of Table 4 show the estimates for different thresholds concerning the high reserves dummy, while keeping the strong fundamentals dummy unchanged. In the second column, the threshold is 1.5 (3 country-years) and in the third column, it is 2 (10 country-years). Column 4 corresponds to the case in which fundamentals are strong if the lending boom is less than $20 \%$ and the real appreciation is less than $5 \%$ ( 9 country-years), while in column 5 these thresholds are both zero (2 cases).

For countries with low reserves and weak fundamentals, the point estimates corresponding to the lending boom $\left(\alpha_{1}\right)$ and the real depreciation $\left(\alpha_{2}\right)$ are very similar to the benchmark estimates in all cases. Furthermore, they are all significant at the $5 \%$ and $10 \%$ level, respectively. The estimates for the remaining parameters are stable. Lastly, the p-values associated with the Wald tests are greater that 0.10 , except in three cases. Since the thresholds we have considered vary over wide ranges, we might conclude that the benchmark results are robust to the way in which we define strong fundamentals and high reserves.

\subsubsection{Fitting Simpler Equations}

We have seen that the benchmark results are robust to the thresholds used to define the dummies for high reserves and strong fundamentals. Would the results remain unchanged if we were to disregard these dummies? To address this issue, we estimate equation (11) eliminating one dummy while leaving the other and then eliminating both. As column 2 of Table 5 shows, eliminating the strong fundamentals dummy does not have any important effect on either the point estimates or on the significance levels. In contrast, if we exclude the high reserves dummy (column 3), the significance of the estimate of $\alpha_{1}$ is eliminated, and the adjusted $R^{2}$ is reduced from 0.40 to 0.11 . Surprisingly, if we exclude both dummies (column 
4), the lending boom and the real depreciation enter significantly and with the correct signs. Note, however, that the point estimate of $\alpha_{1}(0.11)$ is much smaller than the benchmark estimate (0.26), and additionally, that the adjusted $\mathrm{R}^{2}$ is quite small $(0.15)$.

\subsubsection{Outliers}

Observations with large residuals or large leverage are likely to exert undue influence on the regression results. There are several ways to identify such outliers. One simple way is to select the observations with higher than average leverage and larger than average squared residuals. According to this criterion the outliers are Hungary 97, Mexico 94, and Philippines 97. There are also statistics to determine which observations are outliers, such as Cook's distance and Welsch's distance. These statistics are computed by STATA. Using these criteria, the outliers are the three previously listed plus Mexico 97 and Turkey 94.

Table 6 presents the results of estimating equation (11) by eliminating, one at a time, the five outliers mentioned above. In all cases, the point estimates of $\alpha_{1}$ are positive and those of $\alpha_{2}$ are negative. Furthermore, both are significantly different from zero at the $5 \%$ and $10 \%$ levels, respectively.

\subsection{Additional Determinants of Currency Crises}

High government consumption, excessive capital inflows and unsustainable current account deficits have been identified as important determinants of currency crises in some well-known episodes. Here, we analyze whether these variables help explain the cross-country variation in the crisis indices after we have controlled for the lending boom, the real appreciation, and the reserves adequacy ratio. We measure each concept in two ways: as the average ratio to GDP over the four years prior to the onset of the crisis (either 1990-94 or 1992-96), and as the real percentage change during the same periods. In each case we interact the extra variable with the high reserves dummy and the strong fundamentals dummy. The estimated coefficients are presented in Tables $7 \mathrm{a}$ and $7 \mathrm{~b}$.

Our regression estimates indicate that in countries with low reserves and weak fundamen- 
tals, government consumption has a positive effect on the crisis index if the lending boom and real depreciation variables are excluded. As column 1 of Table 7 a shows, the estimated coefficient on government consumption is significantly different from zero at the $10 \%$ level. However, if the lending boom and real depreciation variables are included, government consumption ceases to be significant (column 2). We can interpret this finding as saying that if excessive government consumption leads to a greater crisis, it does so, not directly, but rather through its effects on the lending boom and the real exchange rate. It is interesting to note that the point estimates and significance levels of the coefficients corresponding to the lending boom and real depreciation indices $\left(\alpha_{1}\right.$ and $\left.\alpha_{2}\right)$ in column 2 are very similar to the ones in benchmark equation (12).

Now, we turn our attention to capital inflows. A popular view is that excessive capital inflows must lead eventually to a currency crisis. This is because in a short span of time excessive inflows cannot be efficiently channeled to productive projects. Thus, they end up invested in "white elephant" or "crony" projects. As a result, the economy is not able to generate, over the medium run, the necessary returns to repay investors. It is at this point that the economy becomes vulnerable to a crisis. Column 3 of Table 7 presents the estimates of a regression equation that includes only the capital inflows variable. For countries with low reserves and weak fundamentals, capital inflows enter positively and significantly at the $10 \%$ level. However, if one includes the lending boom, and the real depreciation indices, capital inflows have no effect on the severity of the crisis (column 4). As before, this finding suggests that capital inflows do not have an extra effect on the extent of a crisis beyond the effect they exert on the lending boom and real appreciation.

Next, we consider the ratio of the average current account deficit to GDP. It is frequently argued that countries cannot run large current account deficits for long periods of time. This view is related to the Feldstein-Horioka finding. Here, we consider the average current account over the four years preceding each crisis. Since four years is hardly the long run, we should not expect to see a positive correlation between the current account variable and the crises indices. In fact, the point estimates of the current account variable are negative. 
As before, the estimates are significant only when we exclude the lending boom and real depreciation indices from the regression (see columns 5 and 6).

Finally, Table $7 \mathrm{~b}$ presents estimation results for the case where the extra variables are included as the real percentage change over the four years prior to the onset of the crisis (either 1990-94 or 1992-96). In neither case do the extra variables enter significantly at the $10 \%$ level.

\section{Conclusions}

Our findings suggest that in the recent Tequila and Asian episodes currency crises did not spread in a purely random way. Rather, there is a set of fundamentals that helps explain the cross-country variation of the severity of those crises. We find that crises did not spread to countries with strong fundamentals or high international reserves. Furthermore, within the set of vulnerable countries -those with weak fundamentals and low reserves- we find that the crisis index was increasing in the extent of the lending boom and the severity of the real appreciation experienced by the country.

Furthermore, we find that the same model that explains the spread of the crisis in 1995 also explains the cross-country variation in the 1997 crisis. This finding helps explain why in 1995 the hardest hit countries were Latin American, while in 1997 the South East Asian countries were hit hardest. Prior to the Tequila crisis Latin American countries, on average. had experienced bigger lending booms and more severe real appreciations than South East Asian countries. Interestingly, the opposite is true for the period preceding the Asian crisis.

Note that our findings do not imply that there is a simple relation between fundamentals and the timing of a crisis in a given country. The fact that a country is vulnerable does not imply that it must suffer a crisis in the near future. It only implies that if investors expectations turn pessimistic, a crisis will ensue because the government will be forced to close the external gap through a large depreciation, thereby justifying investor's expectations. To the extent that investors expectations are unpredictable, the timing of a crisis in a particular country is unpredictable. 


\section{Data Appendix}

\section{Real Exchange Rate Depreciation}

Average nominal exchange rates and CPI data were obtained from the IFS CD-ROM (lines rf and 64, respectively) for all countries except Taiwan and Hong Kong. The weighted average of the bilateral real exchange rates (which was computed using CPI's) was then calculated with respect to the yen, the dollar, and the DM to obtain a proxy for the real exchange rate. These weights total one and are proportional to the relative bilateral trade shares with Japan, the US, and the EU. Trade shares were computed from the IMF's Direction of Trade Statistics (1997 Yearbook). Real exchange rate data from JP Morgan was used for Taiwan and Hong Kong. The real depreciation index is the percentage increase in the real exchange rate from 1990 to 1994 for the Tequila crisis and 1992 to 1996 for the Asian crisis.

\section{Lending Boom}

First, we obtained the annual real lending of the banking system to the private sector and state-owned enterprises by subtracting government claims (line 32an) from total domestic credit (line 32), and adjusting for inflation using December CPI's (line 64). We then

computed the Lending Boom index as the percentage change of real lending from 1990 to 1994 for the Tequila crisis and 1992 to 1996 for the Asian crisis.

\section{Reserve Adequacy}

We used the ratio of M2 to total reserves minus gold (line 1Ld) as a proxy for reserve adequacy. M2 was calculated as the sum of money (line 34) and quasi-money (line 35). Reserves were converted to national currency using the monthly exchange rate (line rf). The monthly ratio of November 1994 and June 1997 was used as the index for reserve adequacy for the two crises respectively. Several countries did not have data updated through June 1997, so the most recent measure was used. For Malaysia, Poland, Taiwan, and Hungary the relevant measures are as of November 96, November 96, December 96, and September 97, respectively. This should not be a significant problem as the ratios for these countries are fairly stable over time. 


\section{Crisis Index}

The crisis index was calculated as the weighted average of the percentage depreciation of the nominal exchange rate with respect to the US dollar and the percentage decrease in reserves. For the Tequila crisis we computed the crisis index using November 1994 as the initial point and a particular month in 1995 as the end point. For the Asian crisis, we used May 1997 as the initial point. The weights were determined as follows: for each variable we calculated the precision (the inverse of the variance) of the monthly series over the period 1985-1995. Then for each country we computed the weight of each variable as its precision over the sum of precisions. For several countries, reserve data was not available on a monthly basis for the entire 10-year period and was therefore calculated with the data available from the IFS. Precision for Hong Kong was calculated from mixed frequency data (quarterly for several years and then monthly). Precision for Hungary begins in September 1989. Taiwan is measured from 1994 through 1997. For Poland, precision calculation begins in 1990 when the currency stabilized after the transition to a free market economy. Also, it should be noted that IFS was missing recent reserve information for many years. Reserves were obtained using a variety of sources including The Economist, Bloomberg, and the Central Banks of various countries. In addition, Datastream was used to extend exchange rates. All of these data sources were checked with the previous data from the IFS.

Current Account

Current account data is available from IFS CD-ROM (line 78a1). Average share of current account to GDP between 1990-1994 and 1992-1996 were used for the two crises.

\section{Capital Inflows}

Capital inflows were calculated as the sum of capital account, financial account and Net errors and Omissions (line78bc, line 78bj, and line 78ca from IFS CD-ROM). Average shares of Capital inflows to GDP between 1990-1994 and 1992-1996 were used for the two crises. Unfortunately, this data was not available for Hong Kong and Taiwan.

Government Consumption

Government consumption data is available from IFS CD-ROM (line 91f). Average shares 
of capital inflows to GDP between 1990-1994 and 1992-1996 were used for the two crises. No data was available for Argentina.

Taiwan

Most of the data for Taiwan comes from Financial Statistics, Republic of China with the following exceptions: the real exchange rates data comes from JP Morgan, and total reserve minus gold data comes from FAME international database. 


\section{References}

[1] Berg, Andrew and Catherine Patillo, 1998, "Alternative Approaches to Predicting Currency Crises," mimeo IMF.

[2] Calvo, Guillermo, 1995, "Varieties of Capital Market Crises," mimeo, University of Maryland.

[3] Cole, Harold, and Timothy Kehoe, 1996, "A Self-Fulfilling Model of Mexico's 1994-1995 Debt Crisis." Journal of International Economics, 41, 309-330.

[4] Corsetti, Giancarlo, Paolo Pesenti and Nouriel Roubini, 1998, "What Caused the Asian Currency and Financial Crisis?" mimeo, 1998.

[5] Eichengreen, Barry, Andrew Rose and Charles Wyplosz, 1995, "Exchange Market Mayhem: The Antecedents and Aftermath of Speculative Attacks," Economic Policy, Vol. 21(October), 249-312.

[6] Esquivel, Gerardo and Felipe Larrain, 1998, "Explaining Currency Crises," mimeo.

[7] Frankel, Jeffrey A., and Andrew K. Rose, 1996, "Currency Crashes in Emerging Markets: An empirical Treatment." Journal of International Economics, 41(3): 351-366.

[8] Furman, Jason and Joseph Stiglitz, 1998, "Economic Crises: Evidence and Insights From East Asia," Brookings Papers on Economic Activity, No. 2, 1-135.

[9] Glick, Reuven and Andrew Rose, 1998, "Contagion and Trade: Why Are Currency Crises Regional?" mimeo.

[10] Kaminsky, Graciela, Saul Lizondo, and Carmen M. Reinhart, 1998, "Leading Indicators of Currency Crisis," IMF Staff Papers, Vol. 45(1), 1-48.

[11] Kaminsky, Graciela and Carmen M. Reinhart, 1999, "The Twin Crises: the Causes of Banking and Balance-of-Payments Problems," American Economic Review; June. 
[12] Kaminsky, Graciela, 1998, "Currency and Banking Crises: The Early Warnings of Distress," mimeo.

[13] Obstfeld, M., 1996, "Models of Currency Crises With Self-Fulfilling Features," European Economic Review, Vol. 40(April), 1037-47.

[14] Radelet, Steven, and Jeffrey Sachs, 1998, "The Onset of the East Asian Financial Crisis," Harvard Institute for International Development, mimeo.

[15] Sachs, Jeffrey, Aaron Tornell, and Andres Velasco, 1996a, "Financial crises in emerging markets: the lessons of 1995." Brooking Papers on Economic Activity, No.1, 147-217.

[16] Sachs, Jeffrey, Aaron Tornell, and Andres Velasco, 1996b, "The Mexican Peso Crisis: Sudden Death or Death Foretold?" Journal of International Economics.

[17] Sachs, Jeffrey, Aaron Tornell, and Andres Velasco, 1996c, "The Collapse of the Mexican Peso: What have we Learned?" Economic Policy, pp. 13-63. 
Table 1

\begin{tabular}{|c|c|c|c|c|}
\hline $\begin{array}{l}\text { Estimated } \\
\text { Coefficient } \\
\text { and Summary } \\
\text { Statistic }\end{array}$ & $\begin{array}{l}\text { Independent } \\
\text { Variable }\end{array}$ & $\begin{array}{l}\text { Simple } \\
\text { OLS }\end{array}$ & $\begin{array}{c}\text { Random } \\
\text { Effects }\end{array}$ & $\begin{array}{c}-3 \\
\text { Fixed } \\
\text { Effects }\end{array}$ \\
\hline \multirow[t]{2}{*}{$\alpha 1$} & $L B$ & 0.26 & 0.26 & 0.32 \\
\hline & & 0.11 & 0.05 & 0.1 \\
\hline \multirow[t]{2}{*}{$\alpha 2$} & $R E R$ & -0.12 & -0.12 & -0.22 \\
\hline & & 0.06 & 0.11 & 0.14 \\
\hline \multirow[t]{2}{*}{$\alpha 3$} & $L B^{*} D h r$ & -0.26 & -0.26 & -0.35 \\
\hline & & 0.11 & 0.07 & 0.14 \\
\hline \multirow[t]{2}{*}{$\alpha 3$} & $R E R^{*} D h r$ & -0.25 & -0.25 & 0.16 \\
\hline & & 0.36 & 0.73 & 0.39 \\
\hline \multirow[t]{2}{*}{$\alpha 4$} & $L B^{*} D s f$ & 0 & 0 & 0.45 \\
\hline & & 0.26 & 0.28 & 0.17 \\
\hline \multirow[t]{2}{*}{$\alpha 6$} & $R E R^{*} D s f$ & 0.3 & 0.3 & -0.06 \\
\hline & & 0.17 & 0.31 & 0.5 \\
\hline \multirow[t]{2}{*}{$\alpha 7$} & CONSTANT & -4.25 & -4.25 & -4.85 \\
\hline & & 4.14 & 2.93 & 5.72 \\
\hline \multicolumn{5}{|l|}{ SUMMARY STATISTICS } \\
\hline$R 2$ & & 0.48 & 0.48 & 0.82 \\
\hline${ }_{A D S} \boldsymbol{R} 2$ & & 0.4 & & 0.51 \\
\hline
\end{tabular}

Note: the dependent variable is the Crisis Index;

Newey-West Heteroscedasticity adjusted standard errors in italics 
Table 2: Structural Changes

\begin{tabular}{|c|c|c|c|c|c|c|}
\hline $\begin{array}{l}\text { Estimated } \\
\text { Coefficient } \\
\text { and Summary } \\
\text { Statistic }\end{array}$ & $\begin{array}{l}\text { Independent } \\
\text { Variable }\end{array}$ & Benchmark & $\begin{array}{c}\text { Only } \\
94 \text { sample }\end{array}$ & $\begin{array}{c}-3 \\
\text { Only } \\
97 \text { sample }\end{array}$ & -4 & $\overline{-5}$ \\
\hline \multirow[t]{2}{*}{$\alpha 1$} & $L B$ & 0.26 & 0.3 & 0.21 & 0.27 & 0.26 \\
\hline & & 0.11 & 0.17 & 0.07 & 0.013 & 0.11 \\
\hline \multirow[t]{2}{*}{$\alpha 2$} & $R E R$ & -0.12 & -0.23 & -0.06 & -0.12 & -0.21 \\
\hline & & 0.06 & 0.09 & 0.06 & 0.06 & 0.09 \\
\hline \multirow[t]{2}{*}{$\alpha 3$} & $L B^{*} D^{\wedge} h r$ & -0.26 & -0.36 & -0.21 & -0.26 & -0.27 \\
\hline & & 0.11 & 0.2 & 0.06 & 0.1 & 0.11 \\
\hline \multirow[t]{2}{*}{$\alpha 4$} & $R E R^{*} D^{\wedge} h r$ & -0.25 & -0.83 & -0.14 & -0.13 & -0.22 \\
\hline & & 0.36 & 0.83 & 0.19 & 0.53 & 0.35 \\
\hline \multirow[t]{2}{*}{$\alpha 5$} & $L B^{*} D^{\wedge} s f$ & 0 & Dropped & 0.07 & 0 & -0.02 \\
\hline & & 0.26 & & 0.27 & 0.26 & 0.27 \\
\hline \multirow[t]{2}{*}{$\alpha 6$} & $R E R^{*} D^{\wedge} s f$ & 0.3 & 0.51 & -0.01 & 0.29 & 0.29 \\
\hline & & 0.17 & 0.29 & 0.12 & 0.17 & 0.2 \\
\hline \multirow[t]{2}{*}{$\alpha 7$} & CONSTANT & -4.25 & -6.17 & -1.75 & -3.99 & -4.23 \\
\hline & & 4.14 & 6.54 & 2.23 & 3.69 & 4.01 \\
\hline \multirow[t]{2}{*}{$\alpha 8$} & $L B^{*} D 97$ & & & & -0.02 & \\
\hline & & & & & 0.08 & \\
\hline \multirow[t]{2}{*}{$\alpha 9$} & $R E R^{*} D 97$ & & & & & 0.24 \\
\hline & & & & & & 0.13 \\
\hline \multicolumn{7}{|l|}{ SUMMARY STATISTICS } \\
\hline$R 2$ & & 0.48 & 0.53 & 0.52 & 0.49 & 0.5 \\
\hline$A D J \boldsymbol{R} \mathbf{2}$ & & 0.4 & 0.39 & 0.34 & 0.39 & 0.41 \\
\hline
\end{tabular}


Table 3

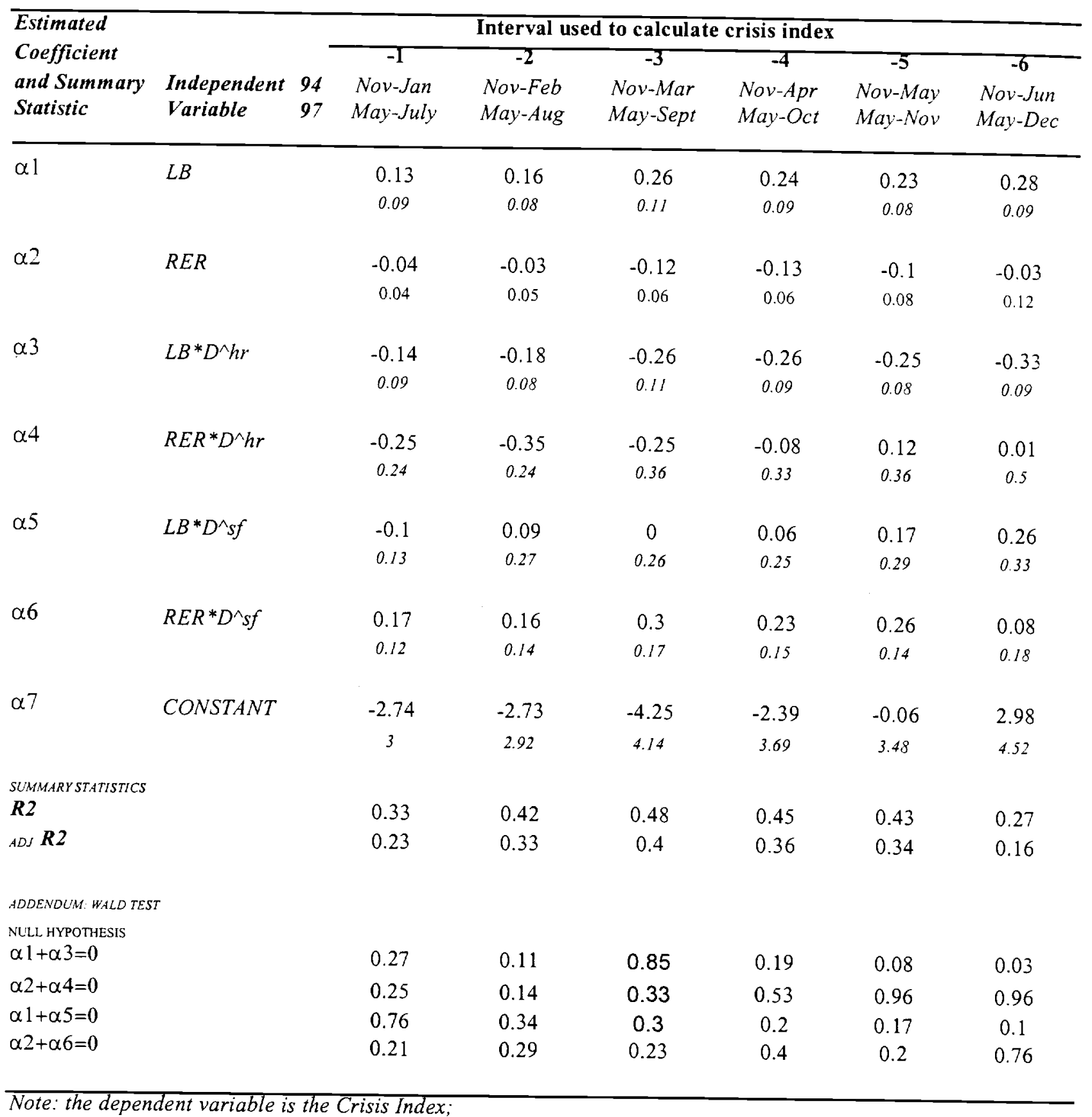

Newey-West Heteroscedasticity adjusted standard errors in italics. 
Table 4

\begin{tabular}{|c|c|c|c|c|c|c|}
\hline $\begin{array}{l}\text { Estimated } \\
\text { Coefficient } \\
\text { and Summary } \\
\text { Statistic }\end{array}$ & $\begin{array}{l}\text { Independent } \\
\text { Variable }\end{array}$ & $\begin{array}{c}\text { Benchmark } \\
R A<1.8 \\
R E R>-5 \% \\
L B<0 \%\end{array}$ & $\begin{array}{c}-2 \\
R A<1.5 \\
R E R>-5 \% \\
L B<0 \%\end{array}$ & $\begin{aligned}-\mathbf{3} \\
R A<2.0 \\
R E R>-5 \% \\
L B<0 \%\end{aligned}$ & $\begin{array}{c}-4 \\
R A<1.8 \\
R E R>-5 \% \\
L B<20 \%\end{array}$ & $\begin{array}{c}\mathbf{- 5} \\
R A<1.8 \\
R E R>0 \% \\
L B<0 \%\end{array}$ \\
\hline$\alpha 1$ & $L B$ & $\begin{array}{l}0.26 \\
0.11\end{array}$ & $\begin{array}{l}0.25 \\
0.11\end{array}$ & $\begin{array}{l}0.26 \\
0.11\end{array}$ & $\begin{array}{l}0.26 \\
0.11\end{array}$ & $\begin{array}{l}0.26 \\
0.11\end{array}$ \\
\hline$\alpha 2$ & $R E R$ & $\begin{array}{l}-0.12 \\
0.06\end{array}$ & $\begin{array}{c}-0.12 \\
0.06\end{array}$ & $\begin{array}{c}-0.14 \\
0.07\end{array}$ & $\begin{array}{c}-0.15 \\
0.09\end{array}$ & $\begin{array}{l}-0.12 \\
0.06\end{array}$ \\
\hline$\alpha 3$ & $L B^{*} D^{\wedge} h r$ & $\begin{array}{l}-0.26 \\
0.11\end{array}$ & $\begin{array}{l}-0.2 \\
0.09\end{array}$ & $\begin{array}{c}-0.27 \\
0.11\end{array}$ & $\begin{array}{c}-0.26 \\
0.11\end{array}$ & $\begin{array}{c}-0.26 \\
0.11\end{array}$ \\
\hline$\alpha 4$ & $R E R^{*} D^{\wedge} h r$ & $\begin{array}{c}-0.25 \\
0.36\end{array}$ & $\begin{array}{l}0.82 \\
0.59\end{array}$ & $\begin{array}{c}-0.32 \\
0.2\end{array}$ & $\begin{array}{c}-0.25 \\
0.41\end{array}$ & $\begin{array}{c}-0.23 \\
0.44\end{array}$ \\
\hline$\alpha 5$ & $L B^{*} D^{\wedge} s f$ & $\begin{array}{c}0 \\
0.26\end{array}$ & $\begin{array}{l}-0.2 \\
0.35\end{array}$ & $\begin{array}{l}0.02 \\
0.26\end{array}$ & $\begin{array}{c}-0.03 \\
0.13\end{array}$ & $\begin{array}{c}-0.71 \\
0.14\end{array}$ \\
\hline$\alpha 6$ & $R E R^{*} D^{\wedge} S f$ & $\begin{array}{l}0.3 \\
0.17\end{array}$ & $\begin{array}{l}0.23 \\
0.16\end{array}$ & $\begin{array}{l}0.32 \\
0.17\end{array}$ & $\begin{array}{c}0.29 \\
0.2\end{array}$ & $\begin{array}{l}0.07 \\
0.22\end{array}$ \\
\hline$\alpha 7$ & CONSTANT & $\begin{array}{c}-4.25 \\
4.14\end{array}$ & $\begin{array}{c}-4.21 \\
4.2\end{array}$ & $\begin{array}{c}-4 \\
3.96\end{array}$ & $\begin{array}{c}-4.89 \\
4.2\end{array}$ & $\begin{array}{c}-4.33 \\
3.91\end{array}$ \\
\hline $\begin{array}{l}\text { SUMMARY STATISTICS } \\
\boldsymbol{R} \mathbf{2} \\
\text { ADJ } \mathbf{R} \mathbf{2}\end{array}$ & & $\begin{array}{c}0.48 \\
0.4\end{array}$ & $\begin{array}{l}0.44 \\
0.36\end{array}$ & $\begin{array}{l}0.49 \\
0.41\end{array}$ & $\begin{array}{l}0.49 \\
0.41\end{array}$ & $\begin{array}{l}0.47 \\
0.42\end{array}$ \\
\hline $\begin{array}{l}\text { ADDENDUM: WALD TES } \\
\text { NULL HYPOTHESIS }\end{array}$ & & & & & & \\
\hline$\alpha 1+\alpha 3=0$ & & 0.85 & 0.26 & 0.63 & 0.93 & 0.94 \\
\hline$\alpha 2+\alpha 4=0$ & & 0.33 & 0.25 & 0.03 & 0.36 & 0.45 \\
\hline $\begin{array}{l}\alpha 1+\alpha 5=0 \\
\alpha 2+\alpha 6=0\end{array}$ & & $\begin{array}{c}0.3 \\
0.23\end{array}$ & $\begin{array}{l}0.87 \\
0.42\end{array}$ & $\begin{array}{c}0.26 \\
0.2\end{array}$ & $\begin{array}{l}0.12 \\
0.36\end{array}$ & $\begin{array}{l}0.06 \\
0.79\end{array}$ \\
\hline
\end{tabular}

Note: the dependent variable is the Crisis Index;

Newey-West Heteroscedasticity adjusted standard errors in italics. 
Table 5: Simpler Equations

\begin{tabular}{|c|c|c|c|c|c|}
\hline $\begin{array}{l}\text { Estimated } \\
\text { Coefficient } \\
\text { and Summary } \\
\text { Statistic }\end{array}$ & $\begin{array}{l}\text { Independent } \\
\text { Variable }\end{array}$ & Benchmark & -2 & -3 & -4 \\
\hline \multirow[t]{2}{*}{$\alpha 1$} & $L B$ & 0.26 & 0.25 & 0.11 & 0.11 \\
\hline & & 0.11 & 0.1 & 0.07 & 0.06 \\
\hline \multirow[t]{2}{*}{$\alpha 2$} & $R E R$ & -0.12 & -0.08 & -0.13 & -0.11 \\
\hline & & 0.06 & 0.05 & 0.08 & 0.07 \\
\hline \multirow[t]{2}{*}{$\alpha 3$} & $L B^{*} D^{\wedge} h r$ & -0.26 & -0.25 & & \\
\hline & & 0.11 & 0.11 & & \\
\hline \multirow[t]{2}{*}{$\alpha 4$} & $R E R^{*} D^{\wedge} h r$ & -0.25 & -0.18 & & \\
\hline & & 0.36 & 0.4 & & \\
\hline \multirow[t]{2}{*}{$\alpha 5$} & $L B^{*} D^{\wedge} s f$ & 0 & & -0.85 & \\
\hline & & 0.26 & & 0.09 & \\
\hline \multirow[t]{2}{*}{$\alpha 6$} & $R E R^{*} D^{\wedge} s f$ & 0.3 & & -0.17 & \\
\hline & & 0.17 & & 0.61 & \\
\hline \multirow[t]{2}{*}{$\alpha 7$} & CONSTANT & -4.25 & -3.31 & 2.19 & 0.91 \\
\hline & & 4.14 & 3.35 & 2.35 & 1.94 \\
\hline \multicolumn{6}{|l|}{ SUMMARY STATISTICS } \\
\hline$R 2$ & & 0.48 & 0.47 & 0.19 & 0.19 \\
\hline${ }_{A D J} \boldsymbol{R} \mathbf{2}$ & & 0.4 & 0.42 & 0.11 & 0.15 \\
\hline
\end{tabular}


Table 6

\begin{tabular}{|c|c|c|c|c|c|c|}
\hline \multirow{2}{*}{$\begin{array}{l}\text { Estimated } \\
\text { Coefficient } \\
\text { and Summary } \\
\text { Statistic }\end{array}$} & \multirow[b]{2}{*}{$\begin{array}{l}\text { Indpendent } \\
\text { Variable }\end{array}$} & \multicolumn{5}{|c|}{ All Countries Except } \\
\hline & & $\begin{array}{c}\text { Hungary } \\
94\end{array}$ & $\begin{array}{c}\text { Mexico } \\
94\end{array}$ & $\begin{array}{c}\text { Turkey } \\
94\end{array}$ & $\begin{array}{c}\text { Mexico } \\
97\end{array}$ & $\begin{array}{c}\text { Philippines } \\
\quad 97\end{array}$ \\
\hline \multirow[t]{2}{*}{$\alpha 1$} & $L B$ & 0.3 & 0.14 & 0.26 & 0.26 & 0.26 \\
\hline & & 0.12 & 0.05 & 0.11 & 0.11 & 0.11 \\
\hline \multirow[t]{2}{*}{$\alpha 2$} & $R E R$ & -0.08 & -0.08 & -0.12 & -0.12 & -0.12 \\
\hline & & 0.06 & 0.05 & 0.06 & 0.06 & 0.06 \\
\hline \multirow[t]{2}{*}{$\alpha 3$} & $L B^{*} D^{\wedge} h r$ & -0.3 & -0.15 & -0.26 & -0.26 & -0.26 \\
\hline & & 0.11 & 0.04 & 0.11 & 0.11 & 0.11 \\
\hline \multirow[t]{2}{*}{$\alpha 4$} & $R E R^{*} D^{\wedge} h r$ & -0.43 & -0.03 & -0.25 & -0.25 & -0.25 \\
\hline & & 0.4 & 0.22 & 0.36 & 0.36 & 0.36 \\
\hline \multirow[t]{2}{*}{$\alpha 5$} & $L B^{*} D^{\wedge} s f$ & -0.06 & 0.11 & 0.01 & 0.01 & 0 \\
\hline & & 0.26 & 0.23 & 0.26 & 0.26 & 0.26 \\
\hline \multirow[t]{2}{*}{$\alpha 6$} & $R E R^{*} D^{\wedge} s f$ & 0.32 & 0.14 & 0.24 & 0.32 & 0.3 \\
\hline & & 0.17 & 0.11 & 0.17 & 0.16 & 0.17 \\
\hline \multirow[t]{2}{*}{$\alpha 7$} & CONSTANT & -6.41 & -0.35 & -4.22 & -4.22 & -4.25 \\
\hline & & 4.19 & 1.74 & 4 & 4 & 3.99 \\
\hline \multicolumn{7}{|l|}{ SUMMARY STATISTICS } \\
\hline$\dot{R} 2$ & & 0.53 & 0.35 & 0.48 & 0.48 & 0.48 \\
\hline${ }_{A D J} \boldsymbol{R} \mathbf{2}$ & & 0.46 & 0.24 & 0.4 & 0.4 & 0.4 \\
\hline \multicolumn{7}{|c|}{ ADDENDUM: WALD TESTS } \\
\hline \multicolumn{7}{|l|}{$\begin{array}{l}\text { NULL HYPOTHESIS } \\
\alpha 1+\alpha 3=0\end{array}$} \\
\hline$\alpha 1+\alpha 3=0$ & & 0.98 & 0.42 & 0.85 & 0.85 & 0.85 \\
\hline$\alpha 2+\alpha 4=0$ & & 0.21 & 0.6 & 0.31 & 0.31 & 0.31 \\
\hline$\alpha 1+\alpha 5=0$ & & 0.32 & 0.29 & 0.27 & 0.28 & 0.28 \\
\hline$\alpha 2+\alpha 6=0$ & & 0.12 & 0.56 & 0.4 & 0.16 & 0.23 \\
\hline
\end{tabular}

Note: the dependent variable is the Crisis Index;

Newey-West Heteroscedasticity adjusted standard errors in italics. 
Table 7a: Additional Determinants of Crises

\begin{tabular}{|c|c|c|c|c|c|c|c|}
\hline \multirow{3}{*}{$\begin{array}{l}\text { Estimated } \\
\text { Coefficient } \\
\text { and Summary } \\
\text { Statistic }\end{array}$} & \multirow{3}{*}{$\begin{array}{l}\text { Independent } \\
\text { Variable }\end{array}$} & \multicolumn{6}{|c|}{ Variables added as the average ratio to GDP } \\
\hline & & \multicolumn{3}{|c|}{$\begin{array}{l}\text { Government } \\
\text { Consumption }\end{array}$} & \multicolumn{2}{|l|}{$\begin{array}{l}\text { Capital } \\
\text { Inflows }\end{array}$} & \multirow{2}{*}{$\begin{array}{c}\text { Current } \\
\text { Account } \\
-6\end{array}$} \\
\hline & & -1 & -2 & -3 & -4 & -5 & \\
\hline \multirow[t]{2}{*}{$\alpha 1$} & $L B$ & & 0.25 & & $\overline{0.24}$ & & 0.22 \\
\hline & & & 012 & & 0.1 & & 0.09 \\
\hline \multirow[t]{2}{*}{$\alpha 2$} & $R E R$ & & -0.12 & & -0.1 & & -0.12 \\
\hline & & & 0.08 & & 0.06 & & 0.07 \\
\hline \multirow[t]{2}{*}{$\alpha 3$} & $L B^{*} D^{\wedge} h r$ & & -0.22 & & -0.24 & & -0.23 \\
\hline & & & 0.1 & & 0.1 & & 0.09 \\
\hline \multirow[t]{2}{*}{$\alpha 4$} & $R E R^{*} D^{\wedge} h r$ & & 0.6 & & -0.04 & & -0.2 \\
\hline & & & 0.36 & & 0.55 & & 0.47 \\
\hline \multirow[t]{2}{*}{$\alpha 5$} & $L B^{*} D^{\wedge} s f$ & & 0.19 & & 0.06 & & 0.05 \\
\hline & & & 0.2 & & 0.2 & & 0.18 \\
\hline \multirow[t]{2}{*}{$\alpha 6$} & $R E R^{*} D^{\wedge} s f$ & & 0.41 & & 0.32 & & 0.33 \\
\hline & & & 0.21 & & 0.15 & & 0.14 \\
\hline \multirow[t]{2}{*}{$\alpha 7$} & CONSTANT & 4.65 & -4.67 & 4.55 & -3.77 & 3.76 & -4.13 \\
\hline & & 1.68 & 4.84 & 1.85 & 4.35 & 1.68 & 4.06 \\
\hline \multirow[t]{2}{*}{$\alpha 8$} & added variable $x$ & 0.15 & 0.05 & 0.37 & 0.12 & -0.54 & -0.27 \\
\hline & & 0.11 & 0.07 & 0.26 & 0.17 & 0.33 & 0.24 \\
\hline \multirow[t]{2}{*}{$\alpha 9$} & $x^{*} D^{\wedge} h r$ & -43.22 & 120.7 & -17.15 & 71.35 & -57.36 & -122.86 \\
\hline & & 44.02 & 61.67 & 40.75 & 72.39 & 75.8 & 112.44 \\
\hline \multirow[t]{2}{*}{$\alpha 10$} & $x^{*} D^{\wedge} s f$ & -0.21 & -0.08 & -0.6 & -0.2 & 0.68 & 0.32 \\
\hline & & 0.11 & 0.06 & 0.25 & 0.16 & 0.32 & 0.22 \\
\hline \multicolumn{8}{|l|}{ SUMMARY STATISTICS } \\
\hline$R 2$ & & 0.14 & 0.49 & 0.18 & 0.53 & 0.24 & 0.54 \\
\hline${ }_{A D J} \boldsymbol{R} \mathbf{2}$ & & 0.08 & 0.36 & 0.12 & 0.39 & 0.18 & 0.42 \\
\hline
\end{tabular}


Table 7b: Additional Determinants of Crises

\begin{tabular}{|c|c|c|c|c|c|c|c|}
\hline \multirow{3}{*}{$\begin{array}{l}\text { Estimated } \\
\text { Coefficient } \\
\text { and Summary } \\
\text { Statistic }\end{array}$} & \multirow{3}{*}{$\begin{array}{l}\text { Independent } \\
\text { Variable }\end{array}$} & \multicolumn{6}{|c|}{ Variables added as the average ratio to GDP } \\
\hline & & \multicolumn{3}{|c|}{$\begin{array}{l}\text { Government } \\
\text { Consumption }\end{array}$} & \multicolumn{2}{|c|}{$\begin{array}{l}\text { Capital } \\
\text { Inflows }\end{array}$} & \multirow{2}{*}{$\begin{array}{c}\text { Current } \\
\text { Account } \\
-6\end{array}$} \\
\hline & & -1 & -2 & -3 & -4 & -5 & \\
\hline \multirow[t]{2}{*}{$\overline{\alpha 1}$} & $L B$ & & 0.24 & & 0.27 & & 0.27 \\
\hline & & & 010 & & 0.12 & & 0.11 \\
\hline \multirow[t]{2}{*}{$\alpha 2$} & $R E R$ & & -0.03 & & -0.12 & & -0.1 \\
\hline & & & 0.08 & & 0.06 & & 0.06 \\
\hline \multirow[t]{2}{*}{$\alpha 3$} & $L B^{*} D^{\wedge} h r$ & & -0.24 & & -0.28 & & -0.27 \\
\hline & & & 0.12 & & 0.12 & & 0.11 \\
\hline \multirow[t]{2}{*}{$\alpha 4$} & $R E R^{*} D^{\wedge} h r$ & & -0.14 & & -0.42 & & -0.28 \\
\hline & & & 0.43 & & 0.56 & & 0.36 \\
\hline \multirow[t]{2}{*}{$\alpha 5$} & $L B^{*} D^{\wedge} s f$ & & -0.38 & & -0.36 & & 0.89 \\
\hline & & & 0.15 & & 0.12 & & 0.09 \\
\hline \multirow[t]{2}{*}{$\alpha 6$} & $R E R^{*} D^{\wedge} s f$ & & -0.12 & & 0.63 & & 0.34 \\
\hline & & & 0.17 & & 0.13 & & 0.2 \\
\hline \multirow[t]{2}{*}{$\alpha 7$} & CONSTANT & 6.47 & -2.66 & 7.94 & -3.93 & 7.01 & -4.57 \\
\hline & & 2.41 & 3.21 & 2.74 & 4.31 & 2.64 & 4 \\
\hline \multirow[t]{2}{*}{$\alpha 8$} & added variable: & 36.86 & 20.81 & -0.2 & -0.41 & 0.03 & -0.4 \\
\hline & $x$ & 31.77 & 23.73 & 0.53 & 0.23 & 0.49 & 0.47 \\
\hline \multirow[t]{2}{*}{$\alpha 9$} & $x^{*} D^{\wedge} h r$ & -41.05 & -27.91 & 1.66 & 2.08 & -3.38 & -2.26 \\
\hline & & 32.05 & 42.29 & 4.07 & 1.59 & 2.2 & 2.26 \\
\hline \multirow[t]{2}{*}{$\alpha 10$} & $x^{*} D^{\wedge} s f$ & 34.54 & 55.88 & 8.52 & 11.54 & 4.95 & -5.1 \\
\hline & & 31.53 & 49.33 & 7.17 & 3.32 & 1.98 & 2.12 \\
\hline \multicolumn{8}{|l|}{ SUMMARY STATISTICS } \\
\hline$R 2$ & & 0.15 & 0.51 & 0.05 & 0.5 & 0.02 & 0.51 \\
\hline ADSRZ & & 0.08 & 0.38 & -0.02 & 0.36 & -0.05 & 0.39 \\
\hline
\end{tabular}

Note: the dependent variable is the Crisis Index;

Newey-West Heteroscedasticity adjusted standard errors in italics. 
Figure 1: Actual and Fitted Crises Indices

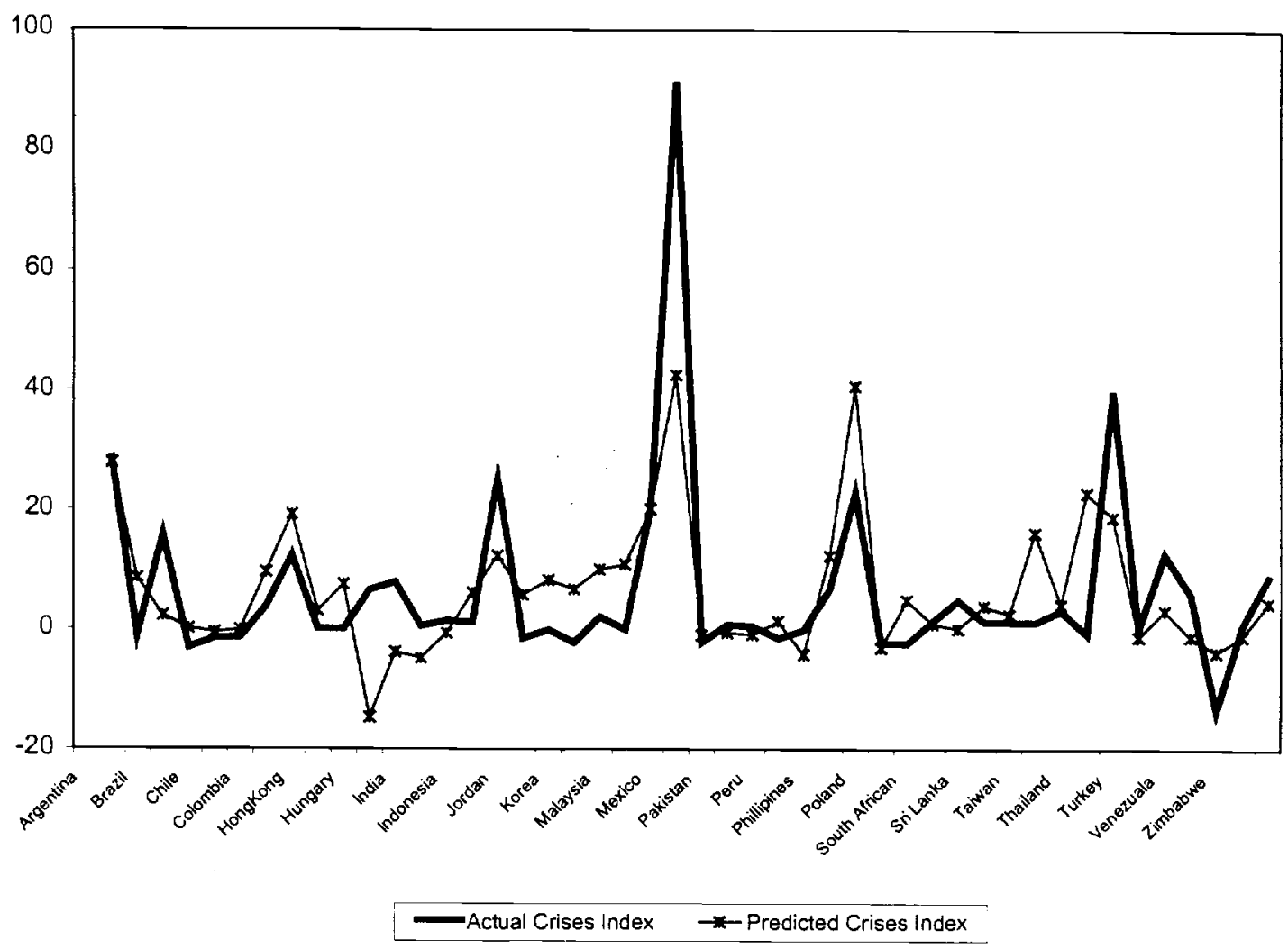

39 
Figure 2: 1997 Crises

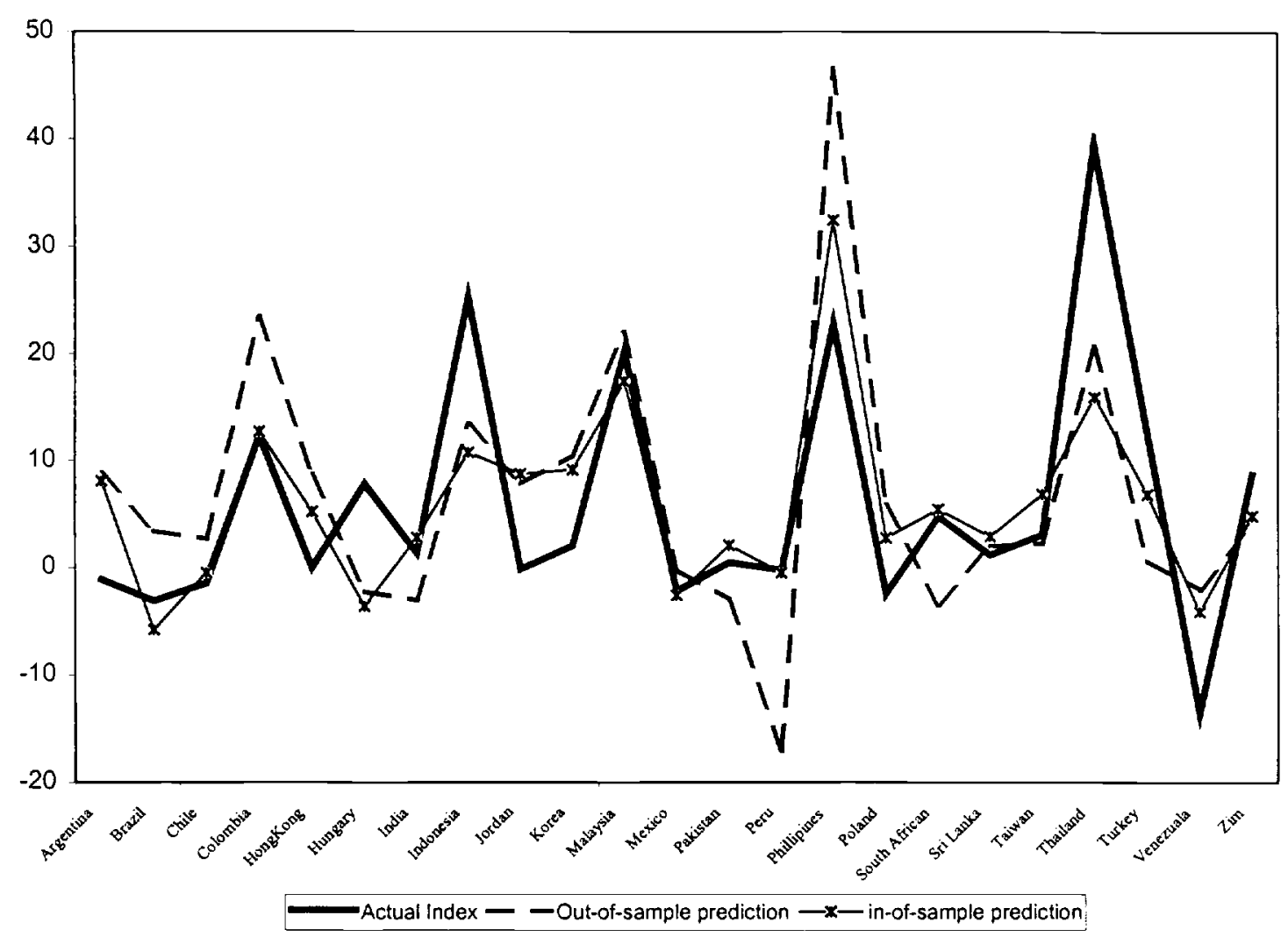

